\title{
Sosialisasi Peran Pemuda-Pemudi dalam Pemilihan Umum (PEMILU) di Nagan Raya Tahun 2019
}

\author{
Yeni Sri Lestari' ${ }^{1}$, Irma Juraida ${ }^{2}$, Triyanto ${ }^{3}$, Dara Quthni Effida ${ }^{4}$ \\ 1,2,3 Jurusan Sosiologi, Universitas Teuku Umar \\ Email: yenilestari24@yahoo.com \\ Email: irmajuraida@utu.ac.id \\ Email: triyanto@utu.ac.id \\ 4 Jurusan Ilmu Hukum, Universitas Teuku Umar \\ Email: daraquthni@utu.ac.id
}

Submitted: 07 November 2019 Revised: 18 November 2019 Accepted: 24 November 2019

\begin{abstract}
Problems in the field show that there is a lack of awareness of young people in the realm of political education. In this case, political education in question is the lack of awareness and awareness of young people to be active and participate in giving their opinions and input to political issues so that they do not participate in the implementation of the General Election has raised challenging issues for the balance of a regional government system. . The implementation of this service is a socialization carried out face to face by delivering material related to the theme of devotion. The results and benefits obtained from the implementation of this socialization are able to foster early awareness of young people to start active in the political process such as exercising their voting rights when elections are held and able to provide motivation for young people to engage directly as a Success Team in supporting prospective couples who have vision-mission according to their views.
\end{abstract}

Keywords: Socialization, Election, Youngster

\begin{abstract}
Abstrak
Permasalahan yang terdapat di lapangan menunjukkan bahwa kurangnya kesadaran pemudapemudi dalam ranah pendidikan politik. Dalam hal ini, pendidikan politik yang dimaksud ialah kurangnya kepedulian dan kesadaran pemuda-pemudi untuk aktif dan ikut serta memberikan pendapat dan masukan mereka kepada persoalan-persoalan politik hingga tidak ikut berpartisipasi dalam pelaksanaan Pemilihan Umum telah menimbulkan persoalan yang menantang bagi keseimbangan sistem pemerintahan sebuah daerah. Pelaksanaan pengabdian ini berupa sosialisasi yang dilaksanakan secara tatap muka dengan menyampaikan materi yang berkaitan dnegan tema pengabdian. Hasil dan manfaat yang diperoleh dari pelaksanaan sosialisasi ini ialah mampu memupuk kesadaran awal pemuda-pemudi untuk mulai aktif dalam proses politik seperti menggunakan hak suaranya ketika Pemilu dilangsungkan serta mampu memberikan motivasi bagi pemuda-pemudi untuk terjun langsung sebagai Tim Sukses dalam mendukung calon pasangan yang memiliki visi-misi sesuai dengan pandangan mereka.
\end{abstract}

Kata Kunci: Sosialisasi, Pemilu, Pemuda

\section{PENDAHULUAN}

Pemuda-pemudi merupakan generasi penerus bangsa yang masih berupaya dan berusaha mencari serta membangun karakter diri untuk memposisikan diri mereka dalam kehidupan bermasyarakat, hal ini khususnya juga dialami oleh pemuda-pemudi di Gampong Suak Bilie. Besarnya peranan yang dimainkan oleh pemuda-pemudi Gampong Suak 
Bilie dalam mengakomodir kebutuhan pemuda-pemudinya terutama dalam menciptakan dan membangun rasa solidaritas antar sesama melalui pelbagai kegiatan seperti pembentukan tim sepak bola gampong, tim relawan yang siap diturunkan apabila terdapat hajatan di gampong, dan banyak lagi kegiatan lainnya telah membuktikan bahwa peran pemuda-pemudi di Gampong Suak Bilie begitu berarti dan memberikan banyak manfaat.

Kuatnya rasa kebersamaan antar pemuda-pemudi Gampong Suak Bilie merupakan langkah awal untuk memberikan contoh kepada pemuda-pemudi lainnya dalam menjalin keakraban dan silahturahmi diantara mereka dengan cara membangun dan melakukan kegiatan-kegiatan yang memiliki dampak positif. Hal ini salah satunya dapat menjadi celah untuk membangun pondasi pendidikan politik dikalangan pemuda-pemudi yang secara umumnya masih memiliki pengetahuan dan kesadaran yang minim akan pentingnya peran mereka untuk menciptakan sistem pemerintahan yang baik.

Keakraban yang telah terjalin antar pemuda-pemudi Gampong Suak Bilie juga harus dibarengi dengan adanya upaya untuk meningkatkan kesadaran politik antar sesama sehingga memberikan manfaat yang setidaknya pada level terkecil yaitu pemerintahan gampong dan akan terus meningkat hingga mampu mengawal dan mengawasi sistem pemerintahan yang lebih tinggi. Kesadaran terhadap proses politik oleh pemuda-pemudi tidak lain adalah untuk menciptakan sistem pemerintahan yang seimbang antara pemerintah dengan masyarakat sehingga cita-cita untuk mewujudkan masyarakat madani dapat terwujud, dan hal ini tidak terlepas dari peran pemuda-pemudi yang merupakan generasi penerus bangsa serta masih memiliki harapan yang luas untuk mengejar impiannya yang tentunya didukung dengan adanya kondisi negara yang makmur dan sejahtera.

Pemikiran dan kontribusi pemuda-pemudi merupakan pilar utama kebangkitan bangsa dan negara Indonesia yang telah dibuktikan melalui sejarah. Besarnya peranan yang dimainkan oleh pemuda-pemudi telah banyak memberikan sumbangsih kepada proses perebutan kemerdekaan Negara Kesatuan Republik Indonesia (NKRI) dari penjajah hingga proses terwujudnya era reformasi Indonesia yang kesemuanya tidak terlepas dari kontribusi baik pemikiran maupun tenaga yang dikeluarkan oleh pemuda-pemudi Indonesia.

Perjuangan untuk terus menjaga NKRI patut diteruskan sampai kapanpun, salah satunya ialah 
dengan menciptakan keadaan yang kondusif dalam penyelenggaraan pemerintahan. Oleh karena itu, pemuda-pemudi di Gampong Suak Bilie perlu diberikan motivasi dan dukungan untuk memperjuangkan aspirasinya dalam menentukan dan memilih pemimpin yang dianggap layak untuk memimpin daerahnya. Selain dari pada itu, Kabupaten Nagan Raya yang juga merupakan daerah pemekaran memiliki banyak potensi untuk menjadi daerah maju, tentunya hal ini tidak terlepas dari peran pemuda-pemudi yang peduli akan pembangunan daerahnya.

Praktiknya usaha untuk membangun dan mendukung peran pemuda-pemudi untuk lebih aktif dalam proses politik masih sangat minim, terutama di tingkat gampong. Hal ini terjadi karena biasanya sosialisasi yang dibuat langsung dilakukan pada tingkat yang lebih luas atau besar seperti kecamatan maupun kabupaten sehingga belum mampu merangkul setiap pemuda-pemudi secara lebih intens. Selain itu, keterbatasan tempat dan tamu undangan juga turut menjadi penyebab kurangnya efektif dan efesiennya proses penyebaran materi sosialisasi mengenai peran pemuda-pemudi di tingkat gampong.

Sebagai alternatif untuk memecahkan persoalan tersebut, maka diadakanlah sosialisasi peran pemuda-pemudi yang dimulai pada tingkat-tingkat gampong. Hal ini dilakukan atas dasar asusmsi bahwa sosialisasi yang dimulai pada tingkat terkecil ini akan mampu memberikan perubahan yang lebih signifikan daripada sosialisasi yang langsung diadakan secara besarbesaran.

Gampong Suak Bilie menjadi pilihan pertama dikarenakan letaknya yang berada di Kecamatan Suka Makmue yang merupakan lokasi berdirinya komplek kantor pemerintahan sehingga mereka lebih cepat dan banyak mendengar mengenai isu-isu politik yang terjadi disekitar wilayah perkantoran tersebut. Hal ini tentunya dapat menjadi peluang bagi pemuda-pemudi untuk dapat cepat tanggap dalam merespon kekurangan dan kelebihan pemerintah dalam menyelenggarakan pelayanan kepada masyarakat.

Sistem pemerintahan, khususnya sistem pelayanan publik yang diberikan oleh pemerintah tidak terlepas dari siapakah sosok pemimpin yang memimpin Kabupaten Nagan Raya. Oleh sebab itu, pemuda-pemudi harus mampu memainkan perannya untuk mendorong proses perubahan sistem pemerintahan yang lebih baik melalui Pemilihan Umum (Pemilu) untuk memilih pemimpin yang dirasa layak untuk memimpin Nagan Raya selanjutnya.

Gagasan pendidikan politik di Indonesia diawali dengan 


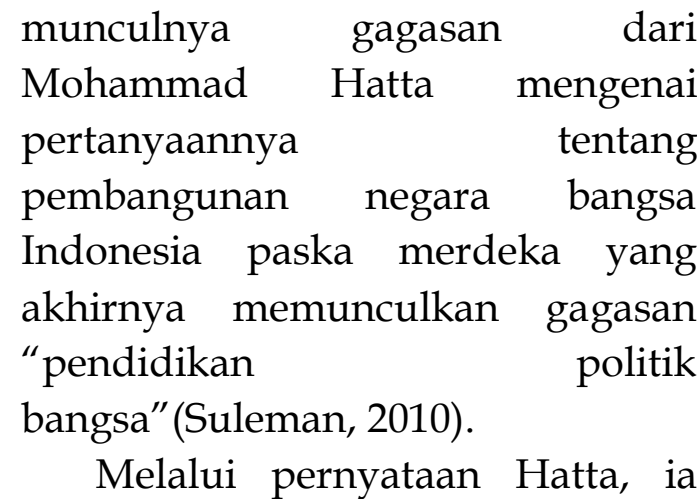
menegaskan apa yang menjadi latar belakang munculnya gagasan pendidikan politik bangsa yaitu "melalui pendidikan, rakyat kecil akan menyadari bahwa bukan hanya pemimpin yang memikul tanggung jawab, tetapi juga semua orang. Bukan hanya pemimpin saja yang harus berjuang, tetapi rakyat juga harus ikut serta. Ada faktor yang sering dilupakan, kemerdekaan Indonesia tidak dapat dicapai hanya oleh pemimpin saja, melainkan oleh usaha dan keyakinan massa. Nasib rakyat Indonesia terletak di tangan rakyat itu sendiri" (Rose, 1991).

Pemikiran Hatta mengenai pendidikan politik bangsa akhirnya meluas sampai kepada ranah pendidikan umum yang harus diketahui oleh masyarakat luas hingga masa kini. Dalam artian yang lebih kontemporer, banyak ahli yang memberikan definisi yang lebih mendalam mengenai pendidikan politik, seperti Alfian menyatakan bahwa "pendidikan politik sebagai usaha yang sadar untuk mengubah proses sosialisasi politik masyarakat sehingga mereka memahami dan menghayati betul nilai-nilai yang terkandung dalam sistem politik yang ideal yang hendak dibangun" (Sunarso, 2007).

Penekanan terhadap pentingnya pendidikan politik ialah untuk merubah proses pemikiran masyarakat luas, bahwa bukan hanya pemerintah saja yang memikirkan persoalan pembangunan bangsa melainkan juga segenap masyarakat bangsa Indonesia. Untuk mewujudkan hal tersebut, maka pendidikan politik diberikan kepada masyarakat luas sebagai sarana untuk mendukung dan memfasilitasi kebutuhan masyarakat Indonesia yang akan terjun dan berpartisipasi dalam pembentukan pemikiran mengenai pembangunan negara bangsa yang lebih baik.

Fungsi pendidikan politik menurut Kartini Kartono ialah memberikan sumbangan yang sangat besar bagi proses demokrasi yang semakin maju dari semua individu (rakyat) dan masyarakat/struktur

kemasyarakatannya serta memberikan sumbangan yang signifikan melalui prinsip-prinsip realistik, lebih manusiawi, dan berlandaskan hukum formal dalam menggalang komunikasi politik yang modern. Berdasarkan fungsi tersebut, maka fungsi pendidikan politik mendorong motivasi kepada masyarakat luas untuk aktif dan partisipatif untuk menciptakan 
sistem pemerintahan yang efektif dan efesien bagi sebuah negara bangsa(Abdulkarim, 2015).

Tujuan pendidikan politik menurut Kartini Kartono yaitu:

Membuat rakyat mampu memahami situasi sosial politik penuh konflik, bersikap tegas memberikan kritik membangun terhadap kondisi masyarakat yang mantap, mengarahkan proses demokratisasi individu, lembaga masyarakat serta lembaga negara serta sanggup memperjuangkan kepentingan dan idea tertentu, khususnya yang berhubungan dengan keamanan dan kesejahteraan hidup bersama(Abdulkarim, 2015).

Memperhatikan dan mengupayakan insani dari setiap individu sebagai warga negara, mengembangkan semua bakat dan kemampuan agar masyarakat bisa aktif berpartisipasi dalam proses politik demi pembangunan diri masyarakat sekitar, bangsa dan negara.

Sosialisasi politik menurut Prewitt \& Dawsondari perspektif sistem merupakan proses dari jalur mana warga negara memperoleh pandangan-pandangan politik yang merupakan sekumpulan cara yang telah menjadi pegangan bagi kehidupan politik bangsanya(Cholisin, 2005). Berdasarkan hal tersebut, maka masyarakat melalui sosialisasi politik dapat menentukan dan menetapkan arah pandangan politiknya yang merupakan dasar bagi terwujudnya partisipasi politik yang lebih matang.

Sosialisasi Politik menurut Almond dan Verba merupakan bagian dari proses sosialisasi yang memiliki tujuan khusus untuk membentuk nilai-nilai politik, yaitu tentang bagaimana seharusnya setiap anggota masyarakat berpartisipasi dalam sistem politik (Sunarso, 2007). Oleh karena itu, sosialisasi politik juga merupakan wadah dasar bagi masyarakat luas untuk mencari lingkup politik yang sesuai dengan karakter pribadi mereka melalui penyesuaian dari beberapa faktor seperti tokoh, visimisi maupun kepentingan.

Sosialisasi politik juga dapat diartikan sebagai cara bagaimana masyarakat menstranmisikan budaya politik dari suatu generasi ke generasi yang lain (Cholisin, 2005). Untuk mencapai usaha penyebarluasan pentingnya pendidikan politik bagi setiap generasi, maka diperlukan adanya sosialisasi politik untuk mewujudkan hal tersebut.

Sosialisasi politik dibagi kedalam dua tipe, pertama Indirect Political Socialization yang terdiri dari interpersonal transference, apprenticeship, dan Generalization. Sedangkan tipe kedua ialah Direct Political Socialization yang terdiri dari imitation, anticipatory 
socialization, political education, dan political experience.

Pemuda merupakan generasi penerus bangsa yang memiliki tugas untuk melanjutkan cita-cita dan perjuangan bangsa, terutama untuk terus membangun negarabangsa yang lebih maju dan bermartabat sehingga akan selalu dihargai oleh semua pihak. Pentingnya peran pemuda dalam sebuah negara menjadikan pemuda sebagai agen perubahan sosial dalam segala bidang yang memainkan peranan penting dan signifikan bagi kemajuan sebuah negara-bangsa.

Peran pemuda secara khusus dalam proses politik ialah :

Pemuda sebagai agen perubahan harus dapat mengendalikan proses transisi demokrasi menuju arah yang lebih baik yaitu dapat mengawal terlaksananya proses politik secara adil. Untuk mengawal proses politik tersebut pemuda dapat berpartisipasi baik sebagai penyelenggara, peserta kegiatan maupun pengawas jalannya proses politik.

Pemuda agen penjaga moral dan etika politik dalam proses demokrasi, yaitu proses politik harus dapat berjalan sesuai dengan aturan hukum yang berlaku, sikap dan perilaku politik yang dijalankan harus menjunjung tinggi etika dan sopan santun politik sehingga tidak menerapkan praktik-praktik politik yang kotor, menghalalkan segala cara, ataupun menggunakan caracara kekerasan/premanisme politik.

Pemuda berperan sebagai penjaga demokrasi, menghormati dak dan kewajiban orang lain, menghargai adanya perbedaan pilihan, dan tidak terjebak pada pragmatisme politik sesaat saja.

Terwujudnya peran pemuda secara efektif dan efesien bagi keberlangsungan penyelenggaraan negara maka pemuda harus memiliki beberapa sikap, yaitu:

Komitmen. Pemuda harus memiliki komitmen yang kuat, keteguhan hati, dan konsistensi memperjuangkan serta mewujudkan cita-cita bagi kemaslahatan masyarakat, bangsa, dan negara.

Integritas. Pemuda harus dapat menjunjung tinggi nilai-nilai moral dan etika yang dapat dirasakan dan dilihat dari sikap dan perilaku yang santun dalam berpolitik. Integritas diri merupakan investasi jangka panjang yang harus dijaga sebagai rahmat kebijaksanaan.

Kompetensi. Pemuda harus memiliki kemampuan dan kualitas sumber daya manusia sebagai modal dasar yang harus dikembangkan dan ditingkatkan secara berkala. Kemampuan untuk memahami orang lain, mengidentifikasi dan merumuskan permasalahan, mencari solusi merupakan proses pembelajaran 
dan pendewasaan yang harus terus menerus dikembangkan.

Konstituensi. Pemuda harus memiliki konstituensi yang meliputi dukungan dan jaringan dari sebanyak-banyaknya masyarakat untuk menjalin hubungan baik serta membina jaringan yang telah terbangun merupakan pekerjaan yang tidak boleh diabaikan dalam berkiprah sebagai pemuda. Kepercayaan dan upaya untuk mendapatkan kekuasaan dengan cara-cara elegan seperti mempraktikkan seni pemerintahan, yaitu seni mempengaruhi orang lain untuk menciptakan hal-hal yang lebih positif.

Tujuan kegiatan pengabdian kepada masyarakat melalui kegiatan yang bertajuk "Sosialisasi Peran Pemuda-Pemudi dalam Pemilu Nagan Raya 2019" adalah:

Memberikan motivasi dan dukungan kepada pemuda-pemudi di Gampong Suak Bilie untuk lebih aktif dan partisipatif dalam proses politik, khususnya dalam pelaksanaan Pemilu Nagan Raya tahun 2019.

Membekali peserta dengan pengetahuan, tips, dan contoh praktik dalam mengenali model peran pemuda-pemudi dalam pelaksanaan pemilihan umum khususnya Pemilu Nagan Raya tahun 2019.

Melatih pemuda-pemudi untuk lebih percaya diri pada kemampuan dan pengetahuan yang mereka telah dapatkan di lingkungan sekolah maupun lingkungan sekitar sehinnga dapat membangun korelasi yang lebih kuat dengan masyarakat yang terlebih dahulu telah aktif dalam proses politik.

Kegiatan pengabdian ini memiliki beberapa manfaat baik secara langsung maupun tidak langsung bagi pemuda-pemudi di Gampong Suak Bilie diantaranya dapat meningkatkan pengetahuan dan wawasan serta memupuk rasa percaya diri melalui motivasi yang diberikan untuk lebih aktif dalam proses-proses politik seperti pelaksanaan pemilihan umum.

Alternatif pemecahan masalah dilakukan dengan melaksanakan sosialisasi mengenai peran pemudapemudi dalam Pemilu Nagan Raya 2019. Berdasarkan hal tersebut diharapkan pemuda-pemudi memiliki pengetahuan dan wawasan yang lebih luas mengenai pentingnya peran pemuda-pemudi dalam kegiatan Pemilu Nagan Raya 2019. Peserta diberikan pelbagai macam materi dan juga praktik untuk memberikan motivasi dan meningkatkan minat mereka terhadap pelaksanaan Pemilu.

\section{METODE PELAKSANAAN}

Persiapan Kegiatan Pengabdian kepada Masyarakat

Pelaksanaan Pengabdian kepada Masyarakat harus diawali dengan tahapan menyusun persiapan dalam penyelenggaraan 
sosialisasi agar acara berlangsung secara tertib. Adapun persiapan yang perlu dilakukan adalah sebagai berikut:

Melakukan studi pustaka tentang peran pemuda serta pentingnya pendidikan politik serta sosialisasi politik yang masih jarang diketahui oleh sebagian besar pemuda-pemudi.

Mempersiapkan perlengkapan penunjang acara sosialisasi.

Mengatur tempat serta pengecekan alat-alat peraga yang digunakan dalam Pemilu.

Menenetukan waktu dan lamanya pelaksanaan kegiatan sosialisasi.

Menentukan dan mempersiapkan materi final yang akan dipresentasikan pada acara sosialisasi.

Pelaksanaan Kegiatan Pengabdian

Pelaksanaan kegiatan pengabdian berlangsung pada hari Senin, 17 Januari 2019 yang dimulai pada pukul 09.00 WIB s.d 16.00 WIB. Jumlah peserta yang hadir adalah 30 orang yang terdiri dari pembicara, aparatur pemuda gampong, dan pemuda-pemudi Gampong Suak Bilie. Kegiatan sosialisasi ini diawali dengan pemberian materi yang bertujuan untuk menambah wawasan para peserta dan dilanjutkan dengan memberi arahan berupa beberapa contoh peran pemuda-pemudi dalam Pemilu seperti cara menyampaikan aspirasi, cara memilih pada proses Pemilu, cara mengawasi jalannya Pemilu, dan banyak lagi. Untuk mempermudah pelaksanaan praktik mengenai contoh-contoh peran pemudapemudi dalam Pemilu, maka peserta dibagi menjadi 6 kelompok yang masing-masing terdiri dari 5-6 orang.

Khalayak sasaran yang dipilih adalah organisasi kepemudaan beserta pemuda-pemudi di Gampong Suak Bilie. Tempat yang dipilih adalah Balai Gampong Suak Bilie, Kecamatan Suka Makmue, Nagan Raya.

\section{HASIL DAN PEMBAHASAN}

Berdasarkan hasil diskusi, tanya jawab, dan pengamatan langsung selama kegiatan berlangsung, kegiatan pengabdian kepada masyarakat ini memberikan hasil sebagai berikut:

Meningkatnya pengetahuan dan wawasan peserta sosialisasi mengenai pentingnya keaktifan pemuda-pemudi dalam proses Pemilu maupun dalam proses politik lainnya.

Kemudahan untuk menerima materi karena didukung dengan adanya kegiatan praktik-praktik dari contoh proses politik terutama proses Pemilu.

Meningkatnya motivasi peserta dengan mulai terbentuknya tim-tim kecil yang mendeklarasikan diri sebagai tim pengawas maupun tim sukses dari pasangan calon setelah 
mempelajari visi dan misi pasangan calon.

Faktor-faktor pendukung dalam kegiatan sosialisasi ini adalah besarnya ketertarikan serta minat para pemuda-pemudi di Gampong Suak Bilie karena tema kegiatan yang diberikan bertepatan dengan akan berlangsungnya Pemilu Nagan Raya Tahun 2019 serta adanya rasa keingintahuan yang besar pada sebagian besar peserta terhadap proses politik terutama Pemilu, karena pemuda-pemudi di Kabupaten Nagan Raya dan khususnya di Gampong Suak Bilie melihat bahwa proses Pemilu Nagan Raya merupakan fenomena yang sangat meriah dan berhasil menarik perhatian banyak orang.

Faktor penghambat dalam pelaksanaan kegiatan ini ialah kurangnya waktu pelaksanaan dikarenakan sebagian besar peserta masih berstatus sebagai siswa-siswi di sekolah yang memiliki jadwal sekolah pada pagi hari. Berikut disajikan Gambar 1 dan 2 pada saat sosialisasi Pemilu dengan para pemuda dan pemudi di Gampong Suka Bili.

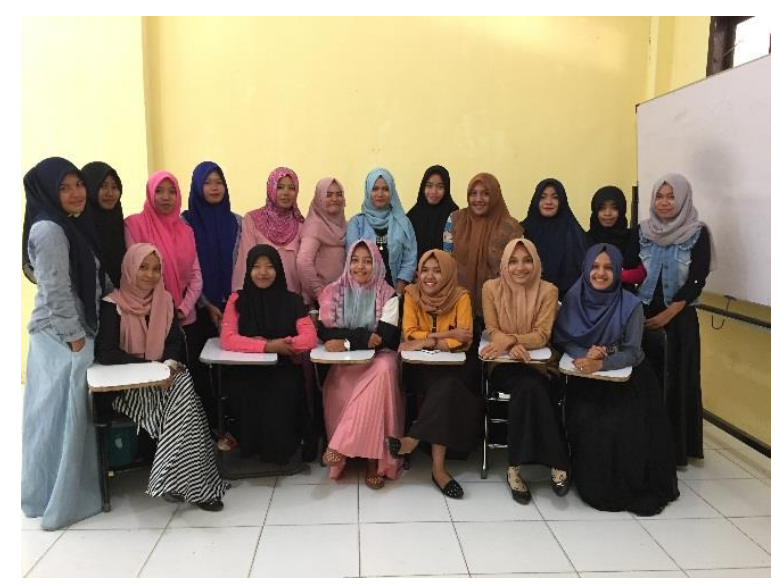

Gambar 1. Sosialisasi dengan Pemudi

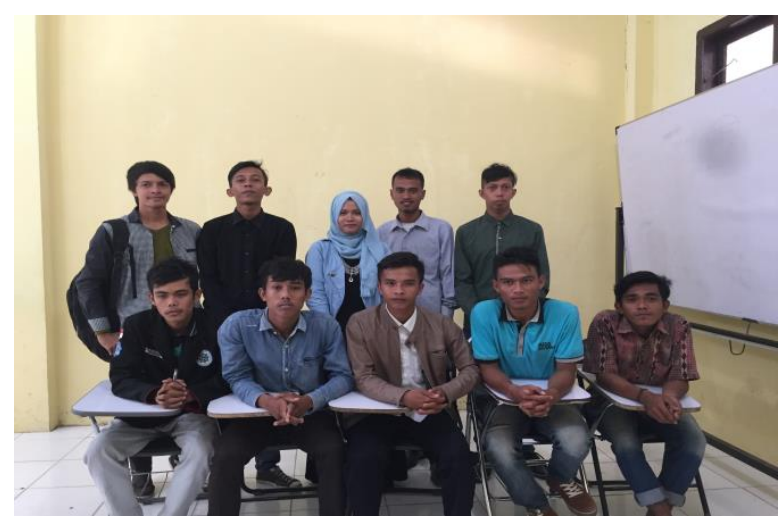

Gambar 2. Sosialisasi dengan Pemuda 
Berikut disajikan Grafik 1 dan 2 terkait dengan peran pemuda yang lebih tinggi bila dibandingkan dengan peran pemudi sebagai agen perubahan, tetapi dari aspek moral dan etika serta partisipasi dalam berdemokrasi justru seimbang antara pemuda dan pemudi di Gampong Suka Bili.

Grafik 1. Tingkat Pemahaman Pemuda-Pemudi Tentang Perannya Dalam PEMILU

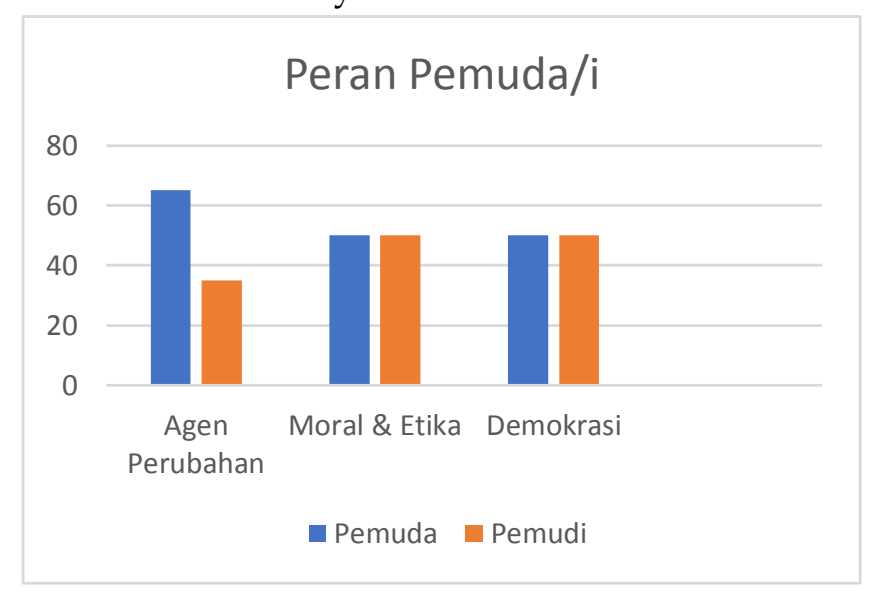

Grafik 2. Sikap Pemuda-Pemudi dalam PEMILU

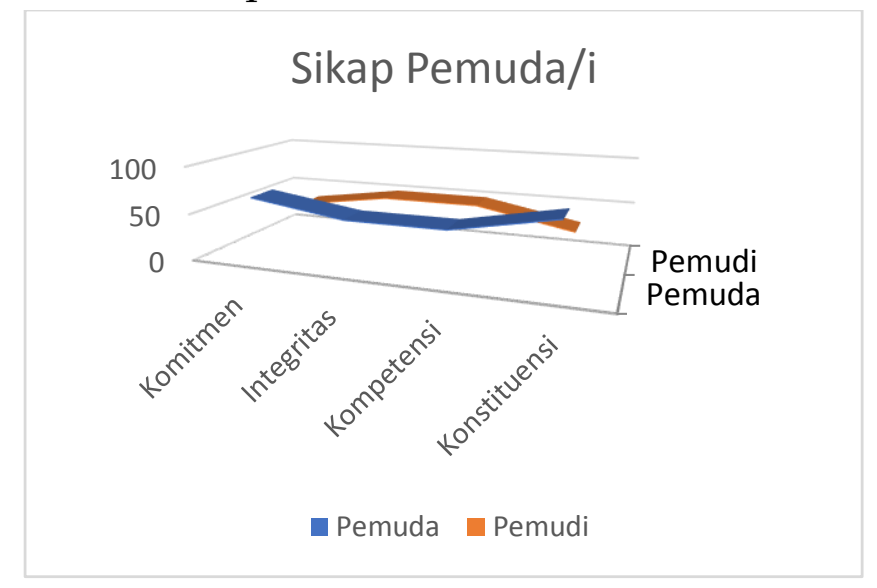

\section{PENUTUP}

Kegiatan pengabdian kepada masyarakat ini disimpulkan beberapa poin, yaitu:

Pengetahuan dan wawasan pemuda-pemudi di Gampong Suak Bilie mengenai pentingnya peran mereka dalam proses politik khususnya proses Pemilu semakin meningkat.

Penguasaan terhadap kegiatankegiatan yang berkaitan dengan proses politik khususnya proses Pemilu semakin terasah dan terarah karena telah disimulasikan melalui 
berbagai bentuk dari praktikpraktik yang telah dicontohkan.

Kegiatan pengabdian kepada masyarakat dalam bentuk ini sangat memberikan manfaat dan kontribusi yang besar bagi pemudapemudi, maka dari itu:

Melaksanakan sosialisasi serupa pada khalayak sasaran di gamponggampong lainnya.

Melaksanakan kegiatan ini secara berkala dan sistematis.

\section{DAFTAR PUSTAKA}

Abdulkarim, A. (2015). Modul Kewarganegaraan.

Cholisin, d. (2005). Dasar-dasar Ilmu Politik. Yogyakarta: UNY.

Rose, M. (1991). Indonesia Merdeka: Biografi Politik Mohammad Hatta. Jakarta: Gramedia Pustaka Utama.

Suleman, Z. (2010). Demokrasi Untuk Indonesia, Pemikiran Politik Bung Hatta. Jakarta: Kompas.

Sunarso. (2007). Pendidikan Politik dan Politik Pendidikan. Jurnal Civics, 19-40.

Suryadi, I. A. (-). Modul Kewarganegaraan. 